\title{
BULL SPERMATOZOA AS OSMOMETERS
}

\author{
L.-O. DREVIUS \\ Institute of Zoophysiology, University of Uppsala, Sweden
}

(Received 4th December 1970, accepted 1st fune 1971)

\begin{abstract}
Summary. The response of epididymal bull spermatozoa to hypotonic media was investigated. Experiments in which spermatocrits were plotted versus the reciprocal of medium osmolality indicate that the swelling of the spermatozoa takes place linearly with a decrease in medium osmolality.

The mean volume and area of swollen spermatozoa at critical medium osmolality (44 mosmol) were calculated as $126 \mu \mathrm{m}^{3}$ and $145 \mu \mathrm{m}^{2}$, respectively. Data available on the isotonic volume, area and water content of the spermatozoa indicate that, at critical medium tonicity, the cells have increased their volume 3.78 to 3.94 times without an apparent increase in area and that, according to conventional osmotic theory, they may be regarded as osmometers with a value of the Ponder's ' $R$ ' correction factor in the range 0.81 to 0.91 , i.e. they seem to deviate from the state of a 'perfect osmometer' by 9 to $19 \%$.
\end{abstract}

\section{INTRODUCTION}

The swollen state of mammalian spermatozoa in hypotonic media can be studied by positive phase-contrast microscopy, when the refractive index of the medium has been increased over that of the cytosol by the addition of albumin or Ficoll (Drevius \& Eriksson, 1966; Drevius, 1968; cf. the immersion-refractometry method of Barer, 1956). The cytosol of the spermatozoa will then appear brighter than the medium, as long as the membrane integrity of the spermatozoa persists. It is observed that during progressive cellular swelling the 'motor apparatus' (axial fibre bundle with mitochondria and fibrous sheath) becomes coiled inside the shape-altering cell membrane in a plane which, in the bull spermatozoon, coincides according to electronmicrographs more or less with that of its 'provisional' plane of symmetry (Drevius \& Eriksson, 1966). This plane sections Fibre 1 and passes between the central fibrils and between Fibres 5 and 6 . This is the plane in which the two-dimensional tail movements of 'abnormally' moving spermatozoa take place (Lindahl \& Drevius, 1964; cf. Rikmenspoel, 1962).

That bull spermatozoa swell in hypotonic media was confirmed by Foote \& Bredderman (1969) and Bredderman \& Foote (1969). On the other hand, bull and ram spermatozoa, which later exhibit coiling of their tails in solutions of low osmotic pressures (Quinn, Salamon \& White, 1968), do not swell in hypotonic media (Quinn \& White, 1969). 
The aim of the present study was to determine the critical tonicity for epididymal bull spermatozoa, i.e. the tonicity which will induce 'hypotonic spermolysis', and the critical volume of the spermatozoa, i.e. their volume at the critical tonicity.

\section{MATERIAL AND METHODS}

Spermatozoa from the cauda epididymidis were obtained as previously described (Drevius, 1968, 1972a).

\section{Isotonic suspending medium}

The medium considered to be isotonic to the spermatozoa was a 0.191 M-NaCl Ringer solution. This consisted of Mann's Ringer solution (1964), in which the $0.9 \%(0.154 \mathrm{M}-) \mathrm{NaCl}$ had been replaced by $0.191 \mathrm{M}-\mathrm{NaCl}, \mathrm{M}$ denoting molality. The osmolality of this Ringer solution is 0.353 , i.e. it is isosmotic with the fluids from the cauda epididymidis (Salisbury \& Cragle, 1956; Drevius, 1972a).

\section{Spermatocrit values}

Determinations on spermatozoa in media of increasing hypotonicities were carried out at $2000 \mathrm{~g}$ for $15 \mathrm{~min}$ at room temperature $\left(23\right.$ to $\left.24^{\circ} \mathrm{C}\right)$ with tubes of the type already described (Drevius, 1971a). Since, in media of tonicity down to approximately $50 \%$ of the isotonic one, the spermatozoa are able to show flagellar movements (though these continuously decrease as the degree of swelling and of change of shape of the cells increase), the cells had first to be rendered immotile. The motility-blocking substance used was NaF. The spermatocrits were determined in solutions of the following compositions: (a) $100 \%$ $\mathrm{NaCl}-\mathrm{NaF}$ Ringer (nine parts of $0.191 \mathrm{M}-\mathrm{NaCl}$ Ringer+one part of 0.191 $\mathrm{M}-\mathrm{NaF}$ Ringer), (b) and (c) 80 and $60 \% \mathrm{NaCl}-\mathrm{NaF}$ Ringer, respectively, being obtained by diluting (a) with distilled water; (d), (e), (f) and (g) 40, 20, 16.6 and $14.3 \% \mathrm{NaCl}$ Ringer, respectively. The fluoride concentrations in (a) to (c) were great enough to inactivate sperm motility (cf. Lindahl \& Wedin, 1963) while, in (d) to (g), motility was blocked as a consequence of cellular swelling. The osmolalities of (a) to (c) were considered to be the same as those of corresponding, fluoride-free, $\mathrm{NaCl}$ Ringer solutions.

The osmolalities of solutions were calculated with the aid of osmotic coefficients for $\mathrm{NaCl}$ solutions of the corresponding concentrations, determined from data given by Robinson \& Stokes (1949) and Giese (1960). Solutions (a) to (g) above correspond osmotically to $\mathrm{NaCl}$ solutions of $0.191,0.153,0.115,0.076$, $0.038,0.032$ and $0.027 \mathrm{~m}$. The corresponding osmotic coefficients were 0.925 , $0.928,0.930,0.937,0.945,0.949$ and 0.953 , and the osmolalities were 0.353 , $0.284,0.214,0.142,0.072,0.061$ and 0.051 , respectively.

\section{Concentrations of spermatozoa in suspensions used in spermatocrit determinations}

The sperm concentration was such that a $2 \cdot 0-\mathrm{ml}$ suspension sample after centrifugation would, under isotonic conditions, give a spermatocrit (uncorrected for trapped extracellular medium) of either $0.010 \mathrm{ml}$ (series A) or 0.020 
$\mathrm{ml}$ (series B). The quantities of stock suspension which, after mixing with a $10.0-\mathrm{ml}$ volume of the different solutions, resulted in the required sperm concentration, were calculated with the aid of a pre-test described earlier (Drevius, 1971a).

Determination of the volume and area of swollen spermatozoa at critical medium tonicity Greatly swollen spermatozoa in $0.023 \mathrm{~m}-\mathrm{NaCl}$ Ringer solution containing 5 to $6 \%$ of Ficoll or in a medium composed of one part of $0.046 \mathrm{M}-\mathrm{NaCl}$ Ringer solution plus one part of 1.7 M-erythritol containing $10 \%$ of Ficoll, were examined through a phase-contrast microscope at a magnification of $\times 320$. They were photographed when the cells were orientated in the medium in thin slide-coverslip preparations as in Text-fig. $1 \mathrm{~A}$ (which is the common orientation almost immediately attained in the preparations) and as in Text-fig. 1 B.

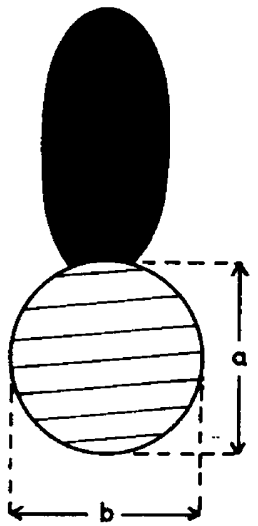

A

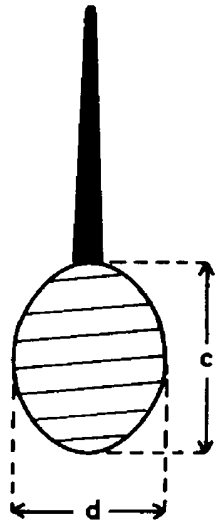

B

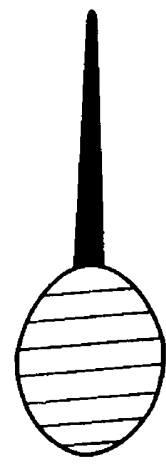

C
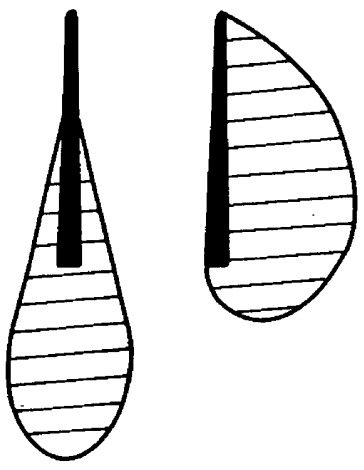

$\mathrm{E}$

Text-FIG. 1. Illustration of the two positions (A and B) in which swollen spermatozoa were photographed at critical medium tonicity. The average lengths of the $a, b$ and $d$ axes will be found in Table 1 . Position $\mathrm{C}$ shows a greatly swollen spermatozoon in which the adherence of the cell membrane to the neck region has been broken (D) and the spatial orientation of the motor-apparatus coil and membrane vesicle changed in relation to the sperm head as a consequence of further swelling (E). The motor apparatus is not indicated (cf, electron micrographs, Figs. 22 to 25 in Drevius \& Eriksson, 1966).

In these positions, the plane of coiling of the motor apparatus in regularly coiled spermatozoa is parallel and perpendicular to the horizontal plane, respectively (cf. electron micrographs in Drevius \& Eriksson, 1966). The Ficoll-containing $0.023 \mathrm{~m}-\mathrm{NaCl}$ Ringer solution had been previously dialysed against a large volume of Ficoll-free Ringer solution. The other medium was prepared by dissolving erythritol in a $10 \%$ Ficoll solution, previously dialysed against distilled water. This mixture was then diluted with one part of 0.046 $\mathrm{M}-\mathrm{NaCl}$ Ringer. The dialyses were performed because the Ficoll preparations contain $\mathrm{NaCl}$.

The rotation of the spermatozoa from Position A to Position B (Text-fig. 1) was produced by currents in the suspensions, initiated by gentle displacements of the coverslip. It is very tedious to record photographically a large number of individual cells in both the A and B positions. Photographs of spermatozoa in 
the B position were therefore collected by numerous 'trial-and-error' exposures of suspensions of drifting cells.

Photographs were projected on a board with the aid of a ballopticon apparatus. The lengths of the $a, b$ and $d$ axes (Text-fig. 1), as well as the lengths of the sperm heads, were registered in twenty-four different spermatozoa. Since the average length of the sperm head, 8.8 $\mu \mathrm{m}$, is known (Bahr \& Zeitler, 1964), the other dimensions were easily obtained.

Organic compounds used in the study

These were Ficoll, mol. wt $\sim 400,000$, chloride (as $\mathrm{NaCl}$ ) $<1 \%$ (Pharmacia $\mathrm{AB})$ and $m$-erythritol (British Drug Houses, Ltd).

\section{RESULTS}

Critical tonicity of the suspending medium

In these experiments, suspensions (approx. $0.5 \%$ ) from eight different stock suspensions were prepared in a series of hypotonic Ringer solutions composed of one part of $0 \cdot 191 \mathrm{M}-\mathrm{NaCl}$ Ringer solution plus 5, 6, 7, 7.5, 8 and 8.5 parts of water, respectively. The media in which approximately $75 \%$ of the spermatozoa underwent swelling-induced membrane rupture with accompanying 'despiralization', i.e. an abrupt straightening out of the earlier coiled and compressed motor apparatus, were determined (cf. Drevius \& Eriksson, 1966). These events occurred in Ringer solutions diluted $(1+7)$ to $(1+8)$, i.e. in solutions with tonicities corresponding to those of 0.024 to $0.0225 \mathrm{M}-\mathrm{NaCl}$. The critical tonicity was estimated to be $0.023 \mathrm{~m}$. The osmolality of this solution is $2 \times$ $0.023 \times 0.957=0.044$.

\section{Critical volume and area of the spermatozoa}

In the Ficoll-containing $0.023 \mathrm{M}-\mathrm{NaCl}$ Ringer solution, hypotonic swelling of spermatozoa is very rapid (the permeability coefficient of the spermatozoa for water being $234 \times 10^{-4} \mathrm{~cm} \mathrm{sec}^{-1}$, Drevius, 1971b). In the Ficoll-Ringererythritol solution, which is initially hyperosmotic because of its erythritol component (p. 31) the osmotic swelling subsequently induced by the penetration of erythritol is much slower (cf. Drevius \& Eriksson, 1966; Drevius, 1972b)

According to osmotic theory, the swelling of the spermatozoa in both of the above-mentioned solutions will cease when the intracellular concentration of osmotically active particles as a consequence of the cellular uptake of water has been decreased to that of the medium $(0.023 \mathrm{M}$ 'salts'). In a large fraction of the spermatozoa in both media, osmotic equilibrium is not attained because such cells will have undergone prior spermolysis. However, in the remaining greatly swollen spermatozoa, the motor apparatus will be coiled within a nearly spherical membrane vesicle (Text-fig. 1).

The motor apparatus of the swollen spermatozoa in the hypotonic FicollRinger solution was sometimes coiled in an irregular manner. This induced a deviation of the vesicular flagellum from the ideal shape commonly observed in Ficoll-Ringer-erythritol solution. These deviations may be due to the rapidity with which the swelling of cells occurs in the former solution. Most of 
the micrographs of swollen spermatozoa on which the measurements of the different axes in Text-fig. 1 A and B were made (see 'Material and Methods') were, therefore, from cells in Ficoll-Ringer-erythritol solutions. Table 1 summarizes these measurements. The difference in the mean lengths of the $a$ and $b$

\section{TABLE 1}

AVERAGE VOLUME AND MEMBRANE AREA OF SWOLLEN EPIDIDYMAL BULL SPERMATOZOA AT GRITICAL MEDIUM TONICITY

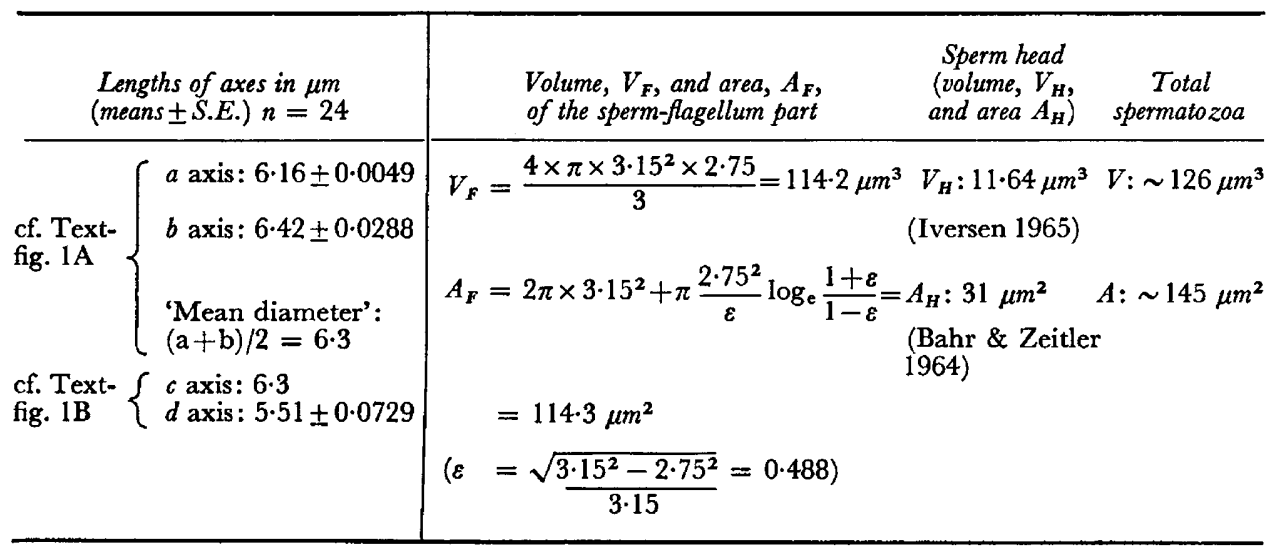

For information on actual parameters and calculations, see 'Material and Methods' and Text-fig. 1.

axes (Text-fig. $1 \mathrm{~A}$ ) was considered to be so insignificant that the projection in the horizontal plane of the vesicular flagellum part of the swollen 'average spermatozoon' was regarded as a circle with a diameter equal to the mean of the $a$ and $b$ axes (Table 1). The area of the horizontal projection of the flagellum part of the swollen spermatozoa in the B position (Text-fig. 1) was considered to be an ellipse, in which the length of the $c$ axis was identical with the mean diameter of the circular area of spermatozoa orientated in the A position.

The average volume and area of the vesicular flagellum part of the 'average spermatozoon', $V_{F}$ and $A_{F}$, respectively (Table 1 ), were calculated with the aid of formulae for the volume and area of an oblate spheroid (see Handbook of Chemistry and Physics, Weast \& Selby, 1966), in which the lengths of the semi-axes were 3.15 and $2.75 \mu \mathrm{m}$, respectively. The total average volume and area of the swollen 'average spermatozoon' were then obtained by adding the known values for the sperm-head volume and sperm-head surface to $V_{F}$ and $A_{F}$, respectively (Table 1).

\section{Spermatocrit determinations on spermatozoa in media of increasing hypotonicity}

The quantities of sperm stock suspensions which were transferred to the different media ( $a$ to $g$ ) to give 'isotonic' spermatocrits of $0.010 \mathrm{ml}$ (and 0.020 $\mathrm{ml}$ ) were $0.173(0.346), 0.162(0.324)$ and $0.146(0.292) \mathrm{ml}$, respectively. On the basis of other experiments, it was known that the cell content of an 'average' stock suspension was approximately a third of the suspension volume. Consequently, when the required volumes of the stock suspensions in $0 \cdot 191 \mathrm{M}-\mathrm{NaCl}$ Ringer were transferred to the hypotonic solutions, their tonicities were 
altered. Appropriate corrections were made in calculating the osmolalities used for constructing Text-fig. 2.

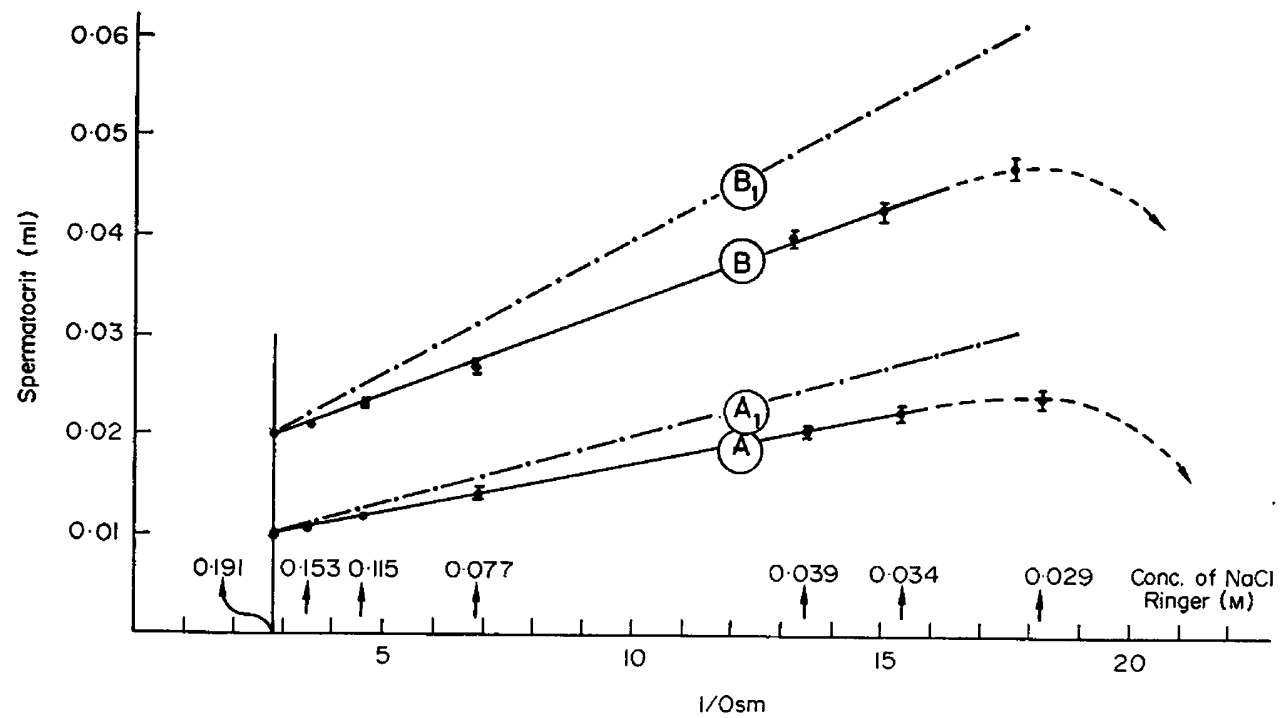

TexT-FIG. 2. Spermatocrits plotted versus the reciprocal of medium osmolality. The spermatocrits recorded, curves A and B (means and ranges of three experiments on pooled spermatozoa), are uncorrected for trapped extracellular medium (TEM) in the cell columns. Curves $A_{1}$ and $B_{1}$ have been constructed on the basis of the assumptions of $a$ TEM value of $0 \%$ and ' $R$ ' $=0.81$. For further information, see text.

\section{DISGUSSION}

\section{Volume and water content of epididymal bull spermatozoa under isotonic conditions}

The volumes of bull spermatozoa and shed cytoplasmic droplets determined by different authors are shown in Table 2. In investigations (1) to (4), the

\section{TABLE 2}

VOLUMES OF BULL SPERMATOZOA AND CYTOPLASMIC DROPLETS AGGORDING TO DIFFERENT AUTHORS

\begin{tabular}{|c|c|c|}
\hline & Volume $\left(\mu m^{3}\right)$ & Authors \\
\hline 1. Ejaculated spermatozoa * & $22 \cdot 5$ & Benedict, Schumaker \& Davies (1967) \\
\hline 2. Ejaculated spermatozoa* & 25 & Drevius \& Eriksson (1966) \\
\hline 3. Ejaculated spermatozoa $\dagger$ & (Range $23 \cdot 4$ to $27 \cdot 2$ ) & $\begin{array}{l}\text { Bredderman \& Foote (1969); } \\
\text { Foote \& Bredderman (1969) }\end{array}$ \\
\hline 4. Ejaculated spermatozoa $\dagger$ & 19 to 23 & O'Donnell (1969) \\
\hline 5. Ejaculated spermatozoa & 30 & Bishop \& Walton (1960) \\
\hline 6. Cytoplasmic dropletst & $8 \cdot 8$ & $\begin{array}{l}\text { Bredderman \& Foote (1969); } \\
\text { Foote \& Bredderman (1969) }\end{array}$ \\
\hline 7. Cytoplasmic droplets $\dagger$ & 9 to 11 & O'Donnell (1969) \\
\hline $\begin{array}{l}\text { 8. Spermatozoa from caput } \\
\text { epididymidis } \dagger\end{array}$ & 37 to 41 & O'Donnell (1969) \\
\hline
\end{tabular}

* Volumes, in Investigations (1) and (2), calculated on the basis of dimensions given by Saacke (1962) and Bahr \& Zeitler (1964), respectively.

† Volumes determined by electronic sizing (Coulter counter). 
volumes of ejaculated spermatozoa are of about the same order. In the present study, the volume of a spermatozoon from the cauda epididymidis has been taken as $(25 \cdot 2+8 \cdot 8+39) / 2=36 \mu \mathrm{m}^{3}$. As is evident from Table 2, this volume represents the mean of (i) the sum of average volumes of ejaculated spermatozoa and shed cytoplasmic droplets (Drevius \& Eriksson, 1966; Bredderman \& Foote, 1969; Foote \& Bredderman, 1969) and (ii) the volume of epididymal spermatozoa from the caput epididymidis (O'Donnell, 1969). The actual volumes were determined with cells and cytoplasmic droplets suspended in $0.154 \mathrm{M}-\mathrm{NaCl}$. However, the fluids from the cauda epididymidis have an osmolality corresponding to $0.191 \mathrm{M}-\mathrm{NaCl}$ (Drevius, 1971 a, 1972a), and the volume of the actual spermatozoa under strictly isotonic conditions should be between (A) $33.3 \mu \mathrm{m}^{3}$ and (B) $32.0 \mu \mathrm{m}^{3}$ (Table 3).

\section{TABLE 3}

FRACTIONAL WATER CONTENT AND VOLUMES OF GELLS, GELL WATER AND 'GELL SOLIDS' OF BULL SPERMATOZOA FROM THE CAUDA EPIDIDYMIDIS UNDER ISOTONIG CONDITIONS

\begin{tabular}{|c|c|c|c|c|}
\hline $\begin{array}{l}\text { Fractional water content } \\
\left(\mathrm{ml} \text { of } \mathrm{H}_{2} \mathrm{O} / \mathrm{ml} \text { of cells }\right)\end{array}$ & $\begin{array}{c}\text { Sperm volume in } \\
\text { relative units } \\
\text { (regarded as } 1.0 \\
\text { in } 0.154 \mathrm{M}-\mathrm{NaCl} \\
\text { solution) }\end{array}$ & $\begin{array}{c}\text { Sperm volume } \\
\left(\mu \mathrm{m}^{3}\right)\end{array}$ & $\begin{array}{l}\text { Sperm water } \\
\left(\mu m^{3}\right)\end{array}$ & $\begin{array}{l}\text { 'Sperm solids' } \\
\left(\mu m^{3}\right)\end{array}$ \\
\hline (A) 0.512 (determined)* & $\begin{array}{c}0.926^{*} \\
\text { (determined) }\end{array}$ & $\begin{array}{l}36 \times 0.926 \dagger \\
=33.3\end{array}$ & $\begin{array}{l}33.3 \times 0.512 \\
=17.0\end{array}$ & $\begin{array}{l}33 \cdot 3-17 \cdot 0 \\
=16 \cdot 3\end{array}$ \\
\hline (B) 0.474 (expected)* & $\begin{array}{c}0.888^{*} \\
\text { (expected) }\end{array}$ & $\begin{array}{l}36 \times 0.888 \dagger \\
=32.0\end{array}$ & $\begin{array}{l}32.0 \times 0.474 \\
=15.2\end{array}$ & $\begin{array}{l}32 \cdot 0-15 \cdot 2 \\
=16 \cdot 8\end{array}$ \\
\hline
\end{tabular}

* Drevius (1972a); † Sperm volume in $0.154 \mathrm{M}-\mathrm{NaCl}$ solutions, $36 \mu \mathrm{m}^{3}$ (present study). For further information, see text.

Critical tonicity, critical volume and membrane area and Ponder's ' $R$ ' for hypotonic swelling of the spermatozoa

The critical volume and membrane area of the spermatozoa were determined on cells in hypotonic Ringer solutions inducing approximately ${ }^{\prime} 75 \%$ of spermolysis' (p. 32). The critical volume was calculated as $126 \mu \mathrm{m}^{3}$ (Table 1). Since the water content of the average spermatozoon under isotonic conditions ranges from (A) $17.0 \mu \mathrm{m}^{3}$ to (B) $15.2 \mu \mathrm{m}^{3}$ and the volume of the 'cell solids' (i.e. the cell volume minus the volume of cell water) from (A) $16.3 \mu \mathrm{m}^{3}$ to (B) $16.8 \mu \mathrm{m}^{3}$ (Table 3), the volume increase of the average spermatozoon at critical medium tonicity $(0.044$ osmol $)$ might be expected to vary between (A) $(16.3+0.353 \times$ $17 \cdot 0 / 0 \cdot 044) / 33.3=4.57$ times to $(B)(16.8+0.353 \times 15 \cdot 2 / 0 \cdot 044) / 32.0=4.32$ times. However, the critical volume of the average sperm cell in $0.044 \mathrm{osmol}$ Ringer solution is calculated as $126 \mu \mathrm{m}^{3}$ (Table 1); thus, its volume has increased by between (A) $126 / 33.3=3.78$ and (B) $126 / 32.0=3.94$ times (cf. Table 3). The ratio of found to calculated change is Ponder's correction factor ' $R$ ' (Ponder, 1940). In the present case, ' $R$ ' ranges from (A) 3.78/4.57 = 0.81 to (B) $3 \cdot 94 / 4 \cdot 32=0.91$. This deviation of 9 to $19 \%$ from the behaviour of a 'perfect osmometer' is not considered to be large. In fact, these ' $R$ ' values are higher than those frequently found for erythrocytes (Ponder, 1940; Dick, 1959). 
For cells in general, the deviations of Ponder's ' $R$ ' from 1.0 have been explained by (a) an escape of 'salts' from the cells when swelling, (b) the existence in the cells of a mechanical resistance to changes in form and volume and, usually, by (c) the presence in the cells of a fraction of 'bound', osmotically inactive water (see Dick, 1959; Davson, 1960; Bishop \& Surgenor, 1964). The validity of (c) has been questioned by Gary-Bobo \& Solomon (1968) in a basic study on erythrocytes. The question of whether a greatly swollen spermatozoon in a strongly hypotonic medium is in osmotic equilibrium is relevant to (b). The motor apparatus normally gives the spermatozoon a degree of rigidity. It may be assumed that when it is distorted inside the shape-altering membrane of a swelling spermatozoon, the motor apparatus will offer growing resistance to increases in cellular volume because of an increasing 'spring-coil' tension in its structure.

Only small differences in the values of the parameters used for calculation of ' $R$ ' are needed to shift the ' $R$ ' values significantly. Thus, the value of the fractional water content of bull spermatozoa given by Lavon, Volcani \& Danon (1968), 0.685 , would yield an ' $R$ ' value of 0.65 . Furthermore, a critical volume of a higher value may be attained in the spermatozoa if their water uptake, immediately before the moment of rupture of the membrane, caused it to become detached at the neck region, so that the cells came to possess a transient appearance similar to that shown in Text-fig. 1D. Such forms, as well as one similar to that shown in Text-fig. 1E, are frequently encountered among ejaculated rabbit spermatozoa in the neighbourhood of their critical tonicity but seldom among bull spermatozoa, though occasionally some may be noticed (see Fig. 15 in Drevius \& Eriksson, 1966). This indicates that the cell membrane is usually more strongly attached to the neck region of the sperm head in epididymal bull spermatozoa than in ejaculated rabbit spermatozoa.

O'Donnell (1969) pointed out that the volume of spermatozoa from the caput epididymidis was greater than that constituted by ejaculated spermatozoa plus shed cytoplasmic droplets (see Table 2, investigations 4, 7 and 8). This discrepancy may reflect a dehydration of the spermatozoa during their passage from the caput to the cauda. The fact that the specific gravity of the spermatozoa increases during this passage (Lavon, Volcani, Amir \& Danon, 1966; Benedict, Schumaker \& Davies, 1967) supports this suggestion. Therefore the 'isotonic' volume of an epididymal bull spermatozoon from the cauda epididymidis may possibly be closer to that of an ejaculated spermatozoon plus cytoplasmic droplet than to the values considered in the present study (p. 34). Were this the case, ' $R$ ' would become closer to $1 \cdot 0$.

Measurements performed on a small number $(n=5)$ of nearly maximally swollen epididymal spermatozoa in $0.025 \mathrm{~m}-\mathrm{NaCl}$ (Drevius \& Eriksson, 1966) indicated that their membrane area might be 10 to $20 \%$ greater than that of spermatozoa under isotonic conditions. The 'isotonic' membrane area calculated did not, however, include the area of the cytoplasmic droplet. According to Table 2 (6) and (7), the mean volume of a shed cytoplasmic droplet is $(8 \cdot 8+10) / 2=9 \cdot 4 \mu \mathrm{m}^{3}$. The area of such a spherical particle is approximately $21.5 \mu \mathrm{m}^{2}$. Since the area of the sperm head is $31 \mu \mathrm{m}^{2}$ (Table 1) and the area of the flagellum of an ejaculated spermatozoon, calculated from data by Bahr 
\& Zeitler (1964), is $92 \mu \mathrm{m}^{2}$ (Drevius \& Eriksson, 1966), the mean area of a non-swollen epididymal bull spermatozoon should be $(21 \cdot 5+31+92)=144 \cdot 5$ $\mu \mathrm{m}^{2}$. This value is nearly identical with that of the mean area of maximally swollen spermatozoa determined in the present study (Table 1). This excellent agreement should, however, be regarded with some caution because the actual values involve calculated as well as determined data, which may be somewhat uncertain. The results discussed indicate, however, that epididymal bull spermatozoa may be able to increase in volume 3.78 to 3.94 times without considerable changes in membrane area. This may be attributed to the special and interrelated changes in the configurations of the motor apparatus and cell membrane in swelling spermatozoa.

\section{Volume changes in spermatozoa registered by spermatocrit determinations}

Drevius \& Eriksson (1966) concluded that spermatocrit determinations were not suitable for measuring changes in sperm volume, because of the tendency of membranes of swollen spermatozoa to rupture during centrifugation at $4000 \mathrm{~g}$. All these experiments were performed on ejaculated bull spermatozoa which had been stored in seminal plasma for at least $15 \mathrm{hr}$ at 4 to $5^{\circ} \mathrm{C}$. It is evident from the present study that epididymal spermatozoa respond with a linear increase in spermatocrit to an increase in the reciprocal of the medium osmolality (Text-fig. 2) when centrifuged for $15 \mathrm{~min}$ at $2000 \mathrm{~g}$. Microscopical observations showed that no more than 2 to $5 \%$ of spermatozoa swollen in a $0.036 \mathrm{~m}-\mathrm{NaCl}$ Ringer solution, for example, suffer membrane damage during this treatment. The spermatocrits recorded at $1 /$ osmol $=18.2$ (curve A) and 1 /osmol $=17.5$ (curve B), however, are somewhat smaller than would be expected on the basis of the slopes of the curves. This is an indication that some spermatozoa may undergo membrane rupture as a consequence of centrifugal stress in combination with the approaching critical medium tonicity.

The low centrifugal force and the short duration of centrifugation necessarily imply that Curves A and B do not present an accurate relation between the total sperm volume in the suspensions and the medium tonicity. This is because no correction was made for extracellular space in the spermatocrit columns which, in the conditions of centrifugation, must be considerable, and is probably variable in media of different tonicities. Thus, the experimental curves in Text-fig. 2 (A and $B$ ) are less steep than those $\left(A_{1}\right.$ and $\left.B_{1}\right)$ that were drawn on the assumptions of zero extracellular space and an ' $R$ ' value of 0.81 . However, the experimental approach through spermatocrit determinations seem to offer a reasonably routine method for objective descriptions of changes in sperm volume induced in various ways (cf. Drevius, 1972b).

In this paper and in others (Drevius \& Eriksson, 1966; Drevius, 1968, 1972a, b) volume changes of spermatozoa have been discussed, by convention, on the basis of the 'Membrane Thesis' (e.g. Hechter, 1965). According to this thesis, the cell membrane is a rate-limiting barrier to the passage of water and solutes and cellular swelling and shrinking are considered to reflect osmotic processes. On the other hand, according to Ling's 'Association-Induction Hypothesis' (Ling 1969; cf. Troshin, 1966), the protoplasm of the entire cell is a proteinaceous fixed-charge system, into which and from which ions and other solutes 
pass as a consequence of specific adsorption-desorption phenomena and cellular volume changes are manifestations not of osmotic processes but of sol-gel transformations of the protoplasm.

\section{ACKNOWLEDGMENTS}

I am much indebted to Professor P. E. Lindahl for valuable discussions and criticism and to Miss G. Thelin for drawing the figures.

This investigation was supported financially by grants from the HiertaRetzius Foundation and from the Faculty of Mathematics and Science of the University of Uppsala.

\section{REFERENCES}

BAHR, G. F. \& ZertLer, E. (1964) Study of bull spermatozoa. Quantitative electron microscopy. F. Cell Biol. 21, 175.

Barer, R. (1956) Phase contrast and interference microscopy in cytology. In: Physical Techniques in Biological Research, Vol. III. Eds. G. Oster and A. W. Pollister. Academic Press, New York.

Benedict, R. C., Schumaker, V. N. \& Davies, R. E. (1967) The buoyant density of bovine and rabbit spermatozoa. F. Reprod. Fert. 13, 237.

Bishop, C. \& Surgenor, D. M. (1964) The red blood cell. Academic Press, New York.

Bishop, M. W. H. \& WALton, A. (1960) Spermatogenesis and the structure of mammalian spermatozoa. In: Marshall's Physiology of Reproduction, Vol. I, part 2. Ed. A. S. Parkes. Longmans Green, London.

Bredderman, P. J. \& Foote, R. H. (1969) Volume of stressed bull spermatozoa and protoplasmic droplets, and the relationship of cell size to motility and fertility. F. Anim. Sci. 28, 496.

Davson, H. (1960) A text-book of general physiology. Churchill, London.

Dick, D. A. T. (1959) Osmotic properties of living cells. Int. Rev. Cytol. 8, 387.

Drevius, L.-O. (1968) On the mechanism of sperm immobilization induced by normal sera and anti-semen sera. Expl Cell Res. 51, 362.

Drevius, L.-O. (1971a) The 'sperm-rise' test. F. Reprod. Fert. 24, 427.

Drevtus, L.-O. (1971b) Permeability coefficients of bull spermatozoa for water and polyhydric alcohols. Expl Cell Res. (in press).

Drevius, L.-O. (1972a) Water content, specific gravity and concentrations of electrolytes in bull spermatozoa. F. Reprod. Fert. 28, 15.

Drevius, L.-O. (1972b) The permeability of bull spermatozoa to water, polyhydric alcohols and univalent anions and the effects of the anions upon the kinetic activity of spermatozoa and sperm models. F. Reprod. Fert. 28, 41.

Drevius, L.-O. \& ERIKsson, H. (1966) Osmotic swelling of mammalian spermatozoa. Expl Cell Res. 42, 136.

Foote, R. H. \& BREDDERMAN, P. J. (1969) Sizing of aging bull spermatozoa with an electronic counter. 7. Dairy Sci. 52, 117.

Gary-Bobo, C. M. \& Solomon, A. K. (1968) Properties of hemoglobin solution in red cells. F. gen. Physiol. 52, 825.

Giese, A. C. (1960) Cell physiology. W. B. Saunders, Philadelphia and London.

HECHTER, O. (1965) Intracellular water structure and mechanisms of cellular transport. Ann. N.Y. Acad. Sci. 125, 625.

IVERSEN, S. (1965) Volume of untreated and ultrasonically treated bull, boar and human spermatozoa electronically determined. F. Reprod. Fert. 9, 197.

Lavon, U., Volcani, R., AmiR, D. \& Danon, D. (1966) The specific gravity of bull spermatozoa from different parts of the reproductive tract. $\mathcal{F}$. Reprod. Fert. 12, 597.

Lavon, U., VolCaNI, R. \& DANON, D. (1968) Determination of dry-matter percentage of ejaculated and epididymal bull spermatozoa. F. Reprod. Fert. 17, 151.

LiNDAHL, P. E. \& Drevius, L.-O. (1964) Observations on bull spermatozoa in a hypotonic medium related to sperm mobility mechanisms. Expl Cell Res. 36, 632.

LiNDAHL, P. E. \& WEDIN, K. (1963) Spermicidal effects studied with a photographic method. The effect of sodium fluoride. Expl Cell Res. 29, 242.

LiNG, G. N. (1969) A new model for the living cell: a summary of the theory and recent experimental evidence of its support. Int. Rev. Cytol. 26, 1. 
ManN, T. (1964) The biochemistry of semen and of the male reproductive tract. Methuen, London.

O'DonNel, J. M. (1969) Electronic counting and sizing of mammalian spermatozoa and cytoplasmic droplets. 7. Reprod. Fert. 19, 263.

Ponder, E. (1940) The red cell as an osmometer. Cold Spring Harb. Symp. quant. Biol. 8, 133.

Quinn, P.J., Salamon, S. \& White, I. G. (1968) Effect of osmotic pressure and temperature gradients on cold shock in ram and bull spermatozoa. Aust. F. biol. Sci. $21,133$.

Quin,, P. J. \& Whrte, I. G. (1969) Osmotic shock of ram spermatozoa. 7. Reprod. Fert. $18,375$.

Rímenspoel, R. (1962) Biophysical approaches to the measurement of sperm motility. In: Spermatozoan Motility, Ed. D. W. Bishop. Publ. No. 72, Am. Ass. Adv. Sci., Washington D.C.

Robinson, R. A. \& Stokes, R. H. (1949) Tables of osmotic and activity coefficients of electrolytes in aqueous solutions at $25^{\circ} \mathrm{C}$. Trans. Faraday Soc. 45, 612.

SAACKE, R. G. (1962) An electron microscope study of normal bovine spermatozoa and factors affecting structural integrity. Ph.D. thesis, Pennsylvania State University, cited by Benedict, R. C., Schumaker, V. N. \& Davies, R. E. (1967) 7. Reprod. Fert. 13, 237.

Salisbury, G. W. \& Gragle, R. G. (1956) Freezing-point depressions and mineral levels of fluids of the ruminant male reproductive tract. IIIrd Int. Congr. Anim. Reprod., Cambridge, p. 25.

Troshin, A. S. (1966) Problems of cell permeability. Pergamon Press, Oxford.

Weast, R. C. \& Selby, S. M. (Eds) (1966) Handbook of chemistry and physics, 47th edn. The Chemical Rubber Co., New York. 